\title{
DESCOLONIZAR CON LA MINGA VISUAL: UNA PLACA DE VIDRIO Y UN RETRATO DE FAMILIA
}

Artículo de reflexión

http://dx.doi.org/10.14483/udistrital.jour.c14.2016.1.a03

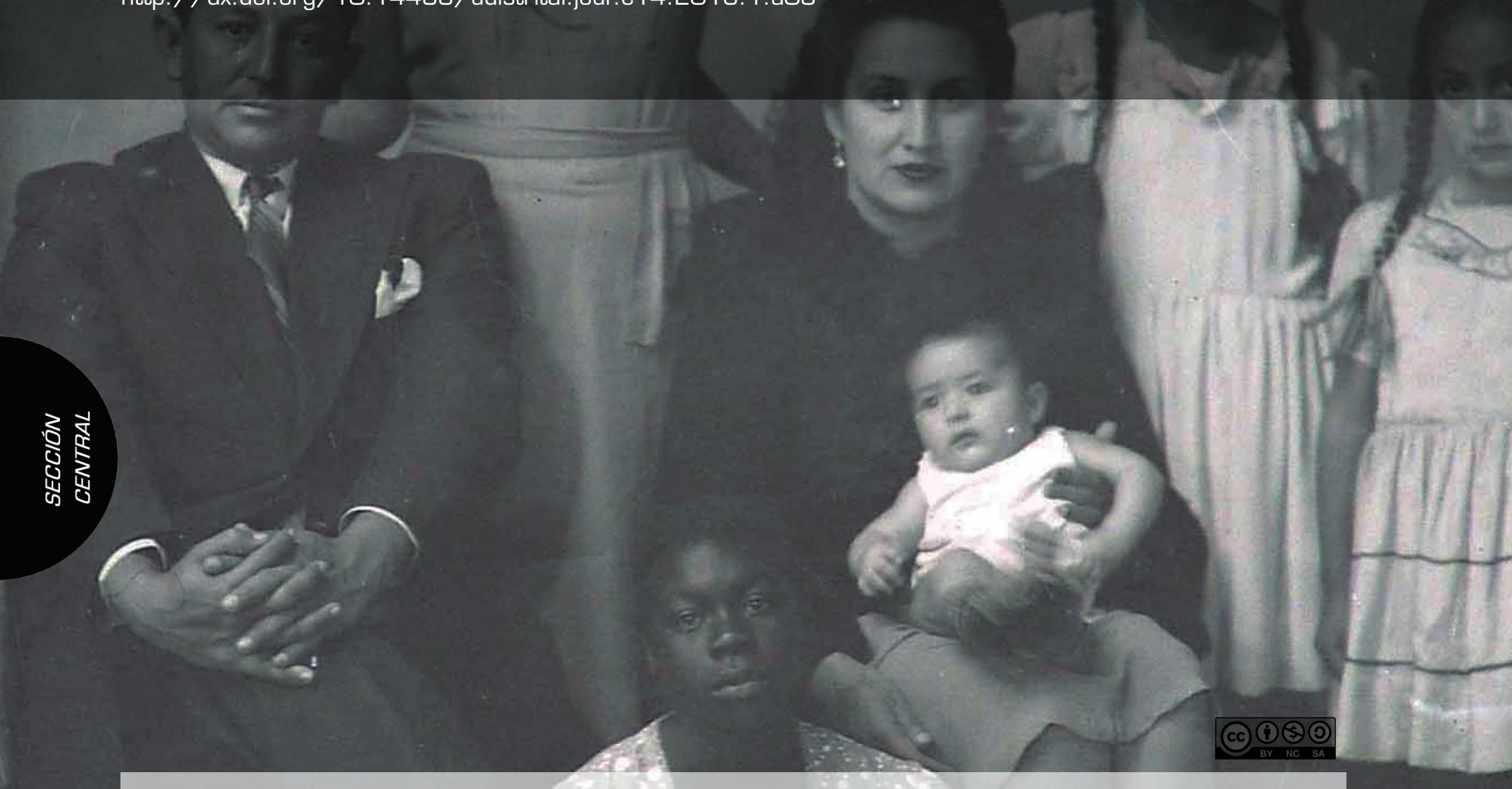

\section{Alex Schlenker}

Universidad Andina Simón Bolívar / hasga@gmx.de

Artista visual y realizador, escritor y traductor. Estudios de cine en el Instituto de Artes Visuales PPF y UW-Films, Alemania; Magíster y Doctor en Estudios Culturales Latinoamericanos por la Universidad Andina Simón Bolívar, Ecuador, en donde se desempeña como docente e investigador en el campo de las visualidades. Es coordinador del proyecto transdisciplinario plataforma_SUR y realizador de los filmes El Duelo (84'/2005), Chigualeros (80'/2009), Distante Cercanía (90'/2013), Dióptero (62'/2014) y Ese breve instante [80'/2015]. Autor de artículos sobre arte, cine y visualidad y de los libros Se busca, Borderlight, Trascamara, Ver y ser visto; ha realizado exposiciones de fotografía, objetos, video-arte e instalaciones. 
Schlenker, A. (2015). Descolonizar con la minga visual: Una placa de vidrio y un retrato de familia. Calle14, 10 (18) pp. 31 - 45

\title{
DESCOLONIZAR CON LA MINGA VISUAL: \\ UNA PLACA DE VIDRIO Y UN RETRATO DE FAMILIA
}

\section{RESUMEN}

Este artículo recoge una serie de reflexiones en torno a las estrategias decoloniales que, desde las llamadas mingas visuales -prácticas artísticas centradas en (re)leer e intervenir imágenes de archivo- desarrollaron dos artistas ecuatorianas entre el 2012 y 2015 para (re)leer la representación fotográfica de género, clase y etnia inscrita en un retrato grupal titulado Retrato de familia, producido por el fotógrafo ecuatoriano Miguel Ángel Rosales en su estudio en la ciudad de lbarra en la década de 1930.

\section{PALABRAS CLAVES}

Fotografía, retrato, familia, racismo, archivo, arte, colonialidad, decolonialidad, minga visual.

\section{MANA MINISTIDU KAWASPALLA RURAI: SUG KILKAI VIDRIOWA RURASKA SUG FAMI- LIARURA}

\section{SUGLLAPI}

Kai mailla kilkapi llullachiku tukuikunata imasami iachaskakuna sutichinga minga kawaspa maquiwa ruraska chagpimanda kawai kallariska ñugpamanda kausaikuna ka iska warm, Ecuador nimanda kai watapi 2012-2015 kawachinaku tukui kaugsai, fotokuna. Pikunami kanchi, kai kilkai sutika. Parla kuna nukanchipa falicunamanda, chasallata sug iacha runa Migeul Angel Rosales mas iachakuspa maipi vida llukskapi kai watapi, 1930.

IMA SUTI RIMAI SIMI:

Fotokuna, kawai, nukanchipura, ñugpamanda rurai, subrigcha minga, kawaspa.

\section{DECOLONIZING WITH A VISUAL MINGA:}

A GLASS PLATE AND A FAMILY PORTRAIT

\begin{abstract}
This article contains a series of reflections on the decolonial strategies which were developed by two Ecuadorian artists, between 2012 and 2015, from the so called visual mingas - artistic practices focused on (re)reading and intervening archival footage - to (re)read the photographic representation of gender, class and ethnicity registered in a group portrait entitled Family Portrait, produced by the Ecuadorian photographer Miguel Angel Rosales in his studio in the city of Ibarra in the 1930s.
\end{abstract}

\section{KEYWORDS}

Photography, portrait, family, racism, archive, art, coloniality, decoloniality, visual minga. 


\title{
DÉCOLONISER AVEC UN MINGA VISUELLE : UNE PLAQUE DE VERRE ET UN PORTRAIT DE FAMILLE
}

\author{
RÉSUMÉ \\ Cet article contient une série de réflexions sur les stratégies décoloniales, qui, à partir \\ de ce qu'on appelle les mingas visuelles - pratiques artistiques axées sur la (re)lecture et \\ l'intervention des images d'archives - ont été développées par deux artistes équatoriens \\ entre 2012 et 2015 pour (re)lire la représentation photographique du genre, des classes \\ et de l'ethnicité enregistrée dans le portrait de groupe Portrait de famille, créé par le photogra- \\ phe équatorien Miguel Angel Rosales dans son atelier dans la ville de lbarra dans les années \\ 1930.
}

\section{MOTS-CLEFS}

Photographie, portrait, famille, racisme, archives, art, colonialité, decolonialité, minga visuelle.

\section{DESCOLONIZAR COM A "MINGA" VISUAL: \\ UMA PLACA DE VIDRO E UM RETRATO DE FAMÍLIA.}

\section{RESUMO}

Este artigo recolhe uma serie de reflexões em torno às estratégias de coloniais que, desde as chamadas "mingas" visuais - práticas artísticas centradas em (re) ler e intervir imagens de arquivo desenvolvido dos artistas equatorianas entre o 2012 e 2015 para (re) ler a representação fotográfica de gênero, aula e etnia inscrita em um relato grupal titulado Retrato de família, produzido pelo fotógrafo equatoriano Miguel Ángel Rosales no seu estudo na cidade de lbarra na década de 1930.

\section{PALAVRAS CHAVES}

Fotografia, retrato, família, racismo, arquivo, arte, colonialidade, decolonialidade, "minga" visual. 
...mi generación creció mirando esas fotos en los álbumes familiares, esos hombres de traje de tres piezas, esas mujeres de guantes y paraguas, gente de otra época en que Bogotá era más fría y más lluviosa y más doméstica, pero no menos ardua. Yo tengo entre mis papeles la foto que mi abuelo compró en los cincuenta y la que mi padre compró unos quince años después. Juan Gabriel Vásquez

El ruido de las cosas al caer

\section{Acechar la imagen de archivo}

Las hijas de pie. La madre sentada en una silla. También el padre ocupa una silla. Las miradas hacia el lente. Solemnidad. Elegancia. Se aproxima el click. Pero hay alguien más: una joven sentada en el suelo, a los pies de él; su color de piel es distinto al del resto del grupo que posa esperando el acto de magia de quien, escondido detrás de la cámara, volverá la escena un instante eterno. El resultado final es una es una placa de vidrio de gran formato tomada presumiblemente en la década de 1930 por el fotógrafo Miguel Ángel Rosales en su Foto Estudio Rosales en la ciudad de Ibarra, Ecuador. El legado fotográfico del Estudio Rosales no incluye apuntes, etiquetas, notas u otras posibles formas para identificar lo retratado. Tales ausencias me llevaron a nombrar la placa de vidrio Retrato de familia, un gesto que repetí en todas las demás imágenes durante la etapa de digitalización. Estos actos de nombrar se fueron convirtiendo en estrategias de enorme utilidad para leer, nombrar y recordar las escenas que posteriormente analicé e intervine. Los nombres, con el avance de la investigación, se volvieron detonadores irónicos que operaban desde la dialéctica imagen-palabra.

Las imágenes de archivo -categoría que adquirieron en el momento de ser rescatadas, recuperadas y clasificadas- que el Estudio Rosales generó a lo largo de más de cinco décadas (1922-1975) de la región de lbarra surgieron en un particular contexto histórico y social. Las distintas formas visuales inscritas en más 45.000 fotografías están atravesadas en su gran mayoría por complejos entramados que ponen en tensión a las élites blanco-mestizas con las poblaciones afrodescendiente e indígena. Cuando uno revisa las fotografías de retrato del Archivo Rosales surge rápidamente la pregunta: ¿quién retrata a quién y para qué? Rosales se convirtió en el cronista de una serie de miradas que se disputaban lugares estratégicos en el encuadre fotográfico. El retrato fotográfico implica una negociación entre retratado y retratante; un formato fotográfico que se apoya en una perspectiva frontal y unos tiempos controlados que, a diferencia del snapshot ${ }^{1}$, permiten desplegar a través de una intencionada puesta en escena determinados relatos de poder, conocimiento, reconocimiento, pertenencia, destrezas, etc. Quienes se retrataban o eran retratados daban cuenta, desde sus deseos más personales e íntimos, de un encuadre fotográfico que recogía buena parte de los juegos de representación y poder de una élite local frente a los grupos históricamente excluidos.

La puesta en escena, en tanto conjunción intencionada y controlada de una serie de elementos expresivos (valor de plano fotográfico, postura corporal, gesto, vestuario, objetos incluidos, iluminación, exposición, etc.), opera como una escritura visual que busca controlar la interpretación de lo representado. El concepto implica que lo escenificado/ representado obedece a la voluntad de un autor. La puesta en escena es ante todo una estrategia de interrelación y potenciamiento de la mirada que un sujeto tiene sobre el mundo. Para los dramaturgos y teóricos Juan Carlos Fontana y Jorge Lavelli la función de la puesta en escena es poner en acción un texto o discurso con fines específicos (2004). El retrato es un formato ideal para tal escenificación discursiva.

La fotografía de archivo, y de manera especial el retrato fotográfico, abre posibilidades para indagar en la construcción histórica de lo que se ha venido llamando la diferencia, aquello que separa y confronta a unos y otros generando estrategias identitarias. La diferencia, inscrita en la dialéctica de aquello que soy/aquello que no soy, es para Stuart Hall central en construcción de la identidad, entendida como la relación de uno y el otro:

Solamente cuando hay un Otro puede uno saber quién es uno mismo. Para descubrir ese hecho hay que evidenciar y desatrancar la larga historia del nacionalismo y del racismo. El racismo es una estructura del discurso y la representación que intenta expulsar simbólicamente al Otro -lo borra, lo coloca allá en el Tercer Mundo, en el margen-.Los ingleses son racistas no porque odien los negros, sino porque no saben quiénes son sin los negros. Tienen que saber quiénes no son, para saber quiénes son (Hall, 1997: 334).

Una forma de escenificación de la diferencia es visible en "Retrato de familia", una fotografía tomada presumiblemente entre 1930 y 1940 . Se trata de buen ejemplo de dos acontecimientos que ocurren durante el ritual del retrato y que deben ser leídos de manera crítica para entender esa diferencia inscrita

1. El término snapshot se refiere a una fotografía espontánea que persigue captar el instante de manera natural y realista sin intervenir sobre lo fotografiado. 
en el control de unos sobre otros. El acontecimiento primario es, sin lugar a dudas, el deseo de una familia acomodada a ser retratada de una manera determinada "para la posteridad" (Sontag, 2006). El acontecimiento que de ahí se desprende es el que finalmente traduce ese deseo en acción, en visualidad dentro del tiempo; un acontecimiento que está compuesto por el movimiento de los retratados previo a la obturación del disparador fotográfico, por las órdenes impartidas por el fotógrafo quien ha recogido los deseos de sus clientes, por las miradas que van y vienen de y hacia la cámara. El segundo acontecimiento ordena el deseo del primero y lo inscribe en los cuerpos retratados, fijando la gramática visual que determina que ciertos sujetos retratados estén de pie (cinco hijas) o sentados sobre sillas (padre y madre) y que "alguien más" ocupe un lugar en el suelo.

Retrato de familia es una fotografía en la que se pueden distinguir tres zonas cartográficas evidentes: la zona de quienes van sentados (en sillas), ocupada por los padres que van al centro de la composición; la zona de quienes van de pie, ocupada por las hijas en los márgenes de la composición y colocadas de manera alternada por sus estaturas (la mayor y más alta al centro entre los padres y las demás niñas repartidas de manera rítmica y alternada a izquierda y derecha); y la zona de la diferencia o del no-ser como el nivel de inferioridad al que ha sido relegada la joven negra, descalza y sentada en el suelo. La "realidad visual" de la imagen no da más información sobre los sujetos de esta foto. ¿Quiénes son? ¿Por qué está la joven afro en la foto y además en el suelo?

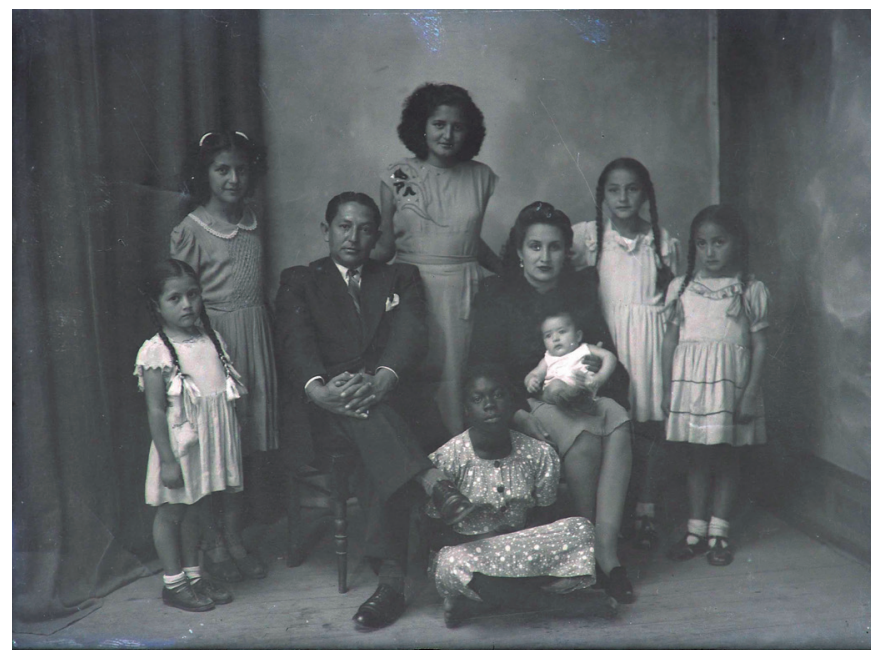

Imagen 1: Retrato de familia, de la serie "Racializando al otro"; Fotografía Estudio Rosales, 1930-40.

Hay múltiples formas para aproximarse a la imagen seleccionada. Uno de estos caminos surge desde la especulación poética accionada desde el gesto artístico. Para el filósofo Armen Avanessian "la experiencia humana, en tanto acto de experienciar de manera estética y conceptual un algo [por ejemplo la fotografía], tiene dos niveles: lo visible/nombrable y lo invisible/ innombrable" (Avanessian; Hennig; s.f.). Así, lo visible o nombrable en Retrato de familia está compuesto por lo que vemos y reconocemos: dos adultos sentados, cinco niñas de pie, un bebé en brazos de su madre (todos mestizos) y una joven afrodescendiente en el suelo; todo ellos en un espacio cerrado (interior) demarcado por tres planos relativamente abstractos (dos paredes y un telón); aparentemente todos se han vestido de manera "especial" para la foto y, además, se han peinado (anudado trenzas). Todos miran a la cámara. Fin de lo visible/nombrable.

Lo invisible/innombrable no está divorciado de lo visible/ nombrable, pero habita gnoseológicamente más allá de lo perceptible, en el campo de la especulación. El acto fotográfico (compuesto por el deseo de los retratados y la técnica del retrato del fotógrafo] conjuga así sus dos dimensiones que solo podrán ser acopladas a partir de la dialéctica de lo certero/posible, formulado a partir de las posibilidades que abre la especulación poética: "¿Existe acaso una experiencia estética que, en la actualidad no sea también una experiencia discursiva? No solo por lo que la obra muestra/dice, sino por lo que de ella se dice" (Avenassian, s.f.], pues la obra y la reflexión que la acompaña suelen estar imbricadas estrechamente.

Vilem Flusser (2010: 13) sugiere entender a las imágenes fotográficas como "superficies significativas" que, generalmente significan (bedeuten] algo exterior. Su función sería entonces la de abstraer ese algo, reduciendo sus cuatro dimensiones (espacio + tiempo) a dos, haciéndolo "imaginable". Para Flusser el sentido de las fotos está inscrito en sus propias superficies y puede ser captado "con la mirada", pero si queremos añadir profundidad a esta aceptación superficial debemos permitir que el desplazamiento de nuestra mirada por la imagen permita reconstruir las dimensiones abstraídas. Habría entonces dos clases de mirada: una superficial, y otra profunda. El registro, que es complejo, depende de dos factores: el ojo y las intenciones que tenemos al observar la imagen e indagar por la joven afro sentada en el piso; el significado resulta finalmente de dos intenciones, la manifiesta en la imagen y la manifiesta en el observador.

\section{Mirar y accionar: las mingas visuales}

Especular en torno a aquello que la imagen fotográfica tiene implica leer y negociar en colectivo. Las imágenes adquieren su sentido a través de la mirada que las significa en un determinado instante de observación? ${ }^{2}$. Las imágenes no son solo símbolos 
denotativos, como los números, sino connotativas, esto es, susceptibles de interpretación. A partir del registro, que establece una relación temporal de un antes y un después, una "dimensión de regreso eterno" (Flusser, 2010: 13) sobre el mismo elemento de la imagen, se establecen las relaciones espaciales que las relaciones llenas de significados, "aquellos conjuntos en los que un elemento les da significado a todos los demás" (Flusser, 2010: 17). Para Flusser queda claro que las imágenes son mediaciones entre el hombre y el mundo. Tienen la finalidad de que el mundo sea accesible e imaginable. Aún así, al interponerse entre el hombre y el mundo, su pretensión de ser mapas las transforma en pantallas y el mundo llega a ser como una imagen, como un contexto de escenas y situaciones. A esto le llama idolatría. Las imágenes técnicas como las llama han empezado a reestructurar mágicamente la realidad, en un escenario semejante a la imagen, con lo que "la imaginación se ha vuelto alucinación" (Flusser, 2010: 17). Entonces, para descifrar las imágenes se debe analizar su "carácter mágico" evitando descifrarlas como si fueran tan solo eventos congelados en el tiempo. La movilidad que la imagen insinúa desde su superficie puede ser leída y (re)activada; en este caso cabe preguntar ¿qué sentido le damos hoy al retrato de la familia mestiza y a la presencia de la joven afro? ¿Cómo responder/intervenir tal escena?

Para especular alrededor de distintas imágenes de archivo desarrollé hace unos años las llamadas mingas visuales, un proyecto transdisciplinar que opera varias veces al año. Se trata de una encuentro en el que distintas personas interesadas en temas visuales -artistas, comunicadores, psicólogos, trabajadores, campesinos, artesanos, vendedores, etc.- se reúnen para (re)leer, discutir e intervenir aquellas imágenes de archivo por las que de algún modo se han sentido interpelados. El concepto para pensar tal estrategia lo tomé del pensamiento del mundo andino: la minga, un modo de hacer con dos acepciones: por un lado es entendida como un "hacer juntos/unidos" y por el otro como posibilidad de irrumpir como "una sola voz".

Las mingas visuales que coordino operan a partir de una superficie (mesa, tabla, cajón, mantel,...) sobre la que coloco alrededor de 200 fotografías.

2. El Foto Estudio Rosales no da ningún indicio sobre la finalidad última de las fotos; al ser la mayoría de imágenes recuperadas negativos guardados en cajas sin ninguna orden de trabajo o copias de las fotografías ampliadas, no ha sido posible rastrear los tamaños a los que las imágenes fueron ampliadas; los posibles tamaños de una fotografía remitirían a sus usos públicos/privados: ¿para llevarla en la billetera, para colocarla en un álbum de fotos, para regalarla a un pariente, para enmarcarla y colgarla en un lugar importante de la casa o del negocio del padre?
Los participantes revuelven las fotografías, seleccionan de manera personal dos o tres e inician una negociación con los demás asistentes sobre qué imágenes deberían ser analizadas y por qué razones. Prácticamente todas las mingas visuales incluyeron Retrato de familia. Incluiré aquí dos de las lecturas/ intervenciones.

Fenomenológicamente no es posible repetir el instante en el que sucedió la toma de la fotografía Retrato de familia, pero hay una posibilidad de reconstrucción especulativa en la que la imagen detona en determinados lectores distintos relatos que explican quiénes están en la fotografía en cuestión y por qué razón. Central a tales relatos es el hecho generalizado que, aunque resulte evidente que se trate de una escena del pasado ${ }^{3}$, se lee una imagen fotográfica relatando lo que en ella acontece en el tiempo gramatical del presente. Así, María Potosí, una indígena de 53 años mira la fotografía y dice que "esa es la primera hija... Iseñala a la chica que está en la mitad), este es el padre, la madre y las hijitas con la nietita...tal vez ella sea adoptada (señalando a la joven afro de la fotol (Potosí, 2011).

En el tiempo del relato fotográfico los personajes del retrato no "fueron", sino que están siendo/existiendo. Este uso del presente en el relato permite ver lo que estaría pasando en el mismo instante en que se habla de la imagen en términos casi binarios: "no no no, las niñas no se visten como si fueran tan ricas, entonces están... simplemente... ni pobres ni ricos." (Potosí, 2011) El testimonio, además de elaborar un correlato de lo que estaría ocurriendo sugiere que en las niñas no es posible advertir una clase social "alta". Así, el pasado del acontecimiento transcurrido hace décadas se funde con la lectura desde el presente generando lo que Avanessian llama una "ficción atravesada por el efecto misterioso que surge cuando se está convencido que no es posible hacer un relato ficcional con verbos en presente, ya que subyace el convencimiento que toda ficción se da en pretérito: la ficción opera con retrospectiva de lo acontecido, haciendo presente el pasado." (Avanessian; Hennig, s.f.).

Las distintas incursiones que en el marco de las mingas visuales detonaron múltiples secuencias visuales que interpelan y desmontan determinados gestos de las imágenes de archivo. Presentaré aquí dos secuencias: Esplendor de una diosa negra (Mayra Cortez, dramaturga y actriz) y Fractales de familia (Daniela Ortiz, artista visual).

3. Varios de los entrevistados se referían en las lecturas a las distintas imágenes como fotografías de "un tiempo de antes" (Armando Ortiz, 206) o "antiguas...son de los tiempos de antes no son de este tiempo" (Blanca Martínez, 210), etc. 


\section{Secuencia 1: "Esplendor de una diosa negra" por: Mayra Cortez}

Mayra Cortez participó en varias mingas visuales en las que realizó su aproximación a Retrato de familia desde el ámbito escénico en el que se desempeña como dramaturga y actriz. En un primer momento reconstruyó la escena retratada a través de un libreto de teatro en el que especula en las posibles relaciones entre quienes han sido retratados en la fotografía. El libreto se sitúa en la temporalidad que le antecede a la obturación fotográfica, a pocos instantes de ser tomada la foto:

(todos se colocan espontáneamente; cuando el tío Luciano está a punto de tomar la fotografía victoria -una de las hijas- grita.J

Victoria: (grita) ¡Espere! ¡Falta alguien!

Don Telmo (el padre): ¿Quién?

Victoria: ¡La Piedadcita!

Don Telmo (el padre): ¡Esa negra no va a salir en mi foto!

Victoria: (molesta) Si no va a salir la Piedadcita, tampoco salga usted, porque la Piedadcita es mi amiga, y para mí es tan importante como usted Papá. Además, el Tío Luciano dice que este aparato sirve para conservar recuerdos agradables, con los seres queridos, y la Piedadcita es mi mejor amiga, es como de la familia y siempre la voy a recordar. (Cortez 2012)

La voz de Victoria, aunque desde la especulación poética, irrumpe con la posibilidad de la coexistencia entre unos y otros en la mirada de la siguiente generación a la de los padres racistas. Victoria y Piedad son "mejores amigas", razón de sobra para que tal amistad sea inmortalizada fotográficamente. Cortez no solo indaga en la posible relación, sino que proyecta desde sus propias experiencias de vida los momentos en que la racializaron por ser afro y además mujer. Así advierte en la joven afro, a la que ha llamado Piedadcita, una mirada de tristeza:

(Piedad observa triste desde la puerta. Las otras niñas lloran].

Luciano (el tío): (Impaciente) ¡Dense prisa! Que un viaje me espera.

Hermanas: ¡Queremos que la Piedadcita salga en la foto!

Doña Clemencia (la madre): ¡Por favor! ¡Déjeles! Es solo una foto ¡Acepte!

Don Telmo acepta a regañadientes con un gesto. [Cortez, 2012/2014: 5-6].

En este punto el relato de Mayra Cortez recupera la voz de la propia autora, quien logra decir a través de sus personajes lo que en cierta manera no ha podido decir en el plano de lo real. Esta acción de elevar la voz hace creer que se ha logrado una cierta igualdad, pero el desenlace, aunque cumple con el deseo de Victoria y Piedad, no se da como ellas quieren:

(Entra Piedad, se coloca al lado de victoria, que está al lado izquierdo de la foto, pero Don Telmo le prohibe).

Don Telmo (el padre): ¡Si se va a tomar la foto con nosotros, que sea en el suelo, ese es su lugar!

[Piedad obedece con tristeza, se sienta en el piso.] (Vemos a victoria al lado izquierdo de la foto, mirando con enojo a la cámara) (Cortez, 2012/2014: 5-6)

Si volvemos del relato a la fotografía veremos que lo descrito en palabras por Mayra Cortez ("mirando con enojo"] se cumple en la imagen:

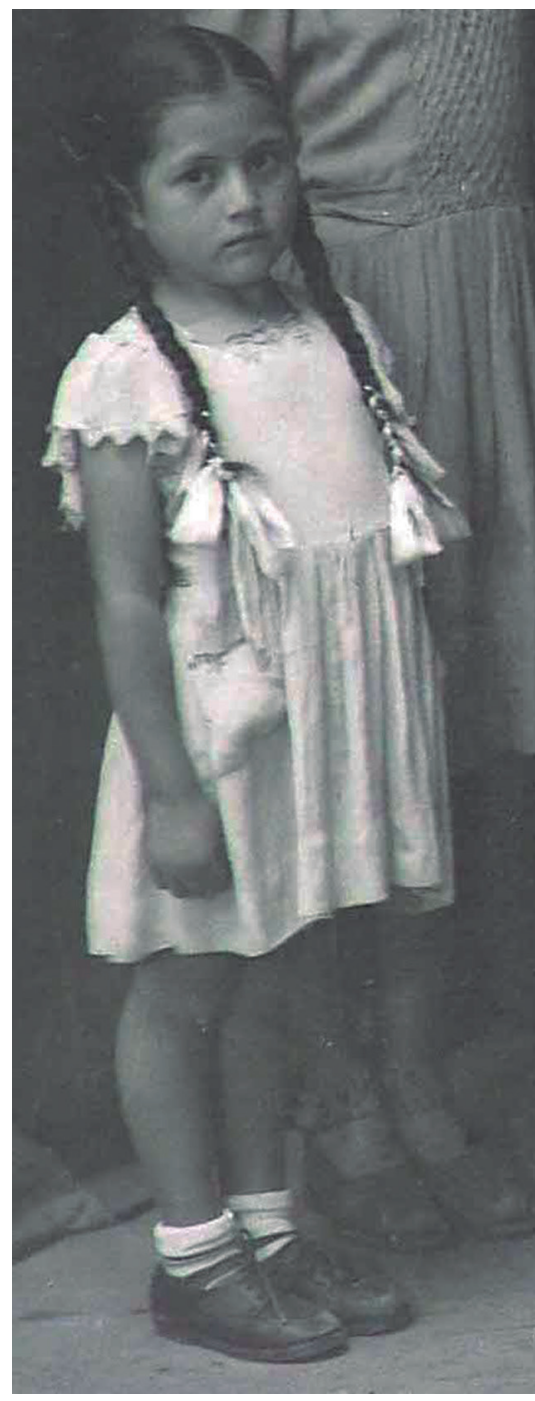

Imagen 2: Retrato de familia (detalle), de la serie "Racializando al otro"; Fotografía: Archivo Rosales, 1930-40.

El relato reconstruye así desde la especulación (poética) las posibilidades "reales" que encierra una imagen fotográfica. Al leer la fotografía se advierte que tras ese instante detenido para la eternidad hay una 
infinidad de otros instantes configurando el tiempo de existencia/resistencia del sujeto retratado. En los intentos por comprender lo acontecido en la sesión de retrato, Mayra Cortez no solo lee la imagen fotográfica, sino que la llega a habitar, proyectándose al interior de su superficie. En varias reuniones de trabajo Mayra fue narrando la historia de su madre, una mujer de origen afroecuatoriano que a temprana edad fue entregada a una familia blanco-mestiza de Quito:

la aparición de la negrita en la foto de familia, realmente es muy extraño, ya que como te contaba, en el álbum, de mi mamá, ella no aparece en ninguna foto. De su niñez, hay solamente una en la que aparece ella sola con un gato, y no hay más fotos de ella, con la familia. [...] mi mamá [...] siempre fue muy querida, por parte de las amistades de esta familia que le crió, a excepción de esta señora que te conté [y que] le prohibía que se lleve con los niños blancos, y también les decía a los niños que no se lleven con mi mamá porque era negra, pero nunca le hicieron caso y solo se ganó la antipatía de la gente, y por eso murió sola. (Cortez, 2012/2014: 2)

Al recuerdo doloroso de Cortez había que sumarle un acto de sanación que pueda operar como mecanismo de desenganche de la colonialidad a la que habían sido sometidas ella y la joven afro de la foto. La propuesta surgió en uno de los talleres de mingas visuales cuando ella sintió, tras sus lecturas de Retrato de familia, que debía descolonizarse a sí misma. Así surgió su proyecto El esplendor de una diosa negra desarrollado en el marco de la minga visual 13. Cortez se propuso generar sus propios retratos a partir del deseo de ser fotografiada como una estrella de cine. La premisa para tal proyecto era la apropiación del sobrenombre de Marylin Monroe, "la diosa blanca" para convertirlo en "el esplendor de una diosa negra". Resulta muy interesante que Mayra se dedicara a la actuación, un oficio que a su madre le fue negado por aquella mujer racista:

cuando mi mamá creció se dedicó a cantar, y estudiar teatro con Fabio Paquioni, ella se presentaba a escondidas en algunas emisoras como Radio Tarqui, ganó premios, y esta mujer le descubrió y le prohibió, argumentando que las artistas se volvían prostitutas. Luego mi mami cayó enferma y nunca más volvió a cantar y peor a actuar. (Cortez, 2012/2014: 2).

La historia de racismo en la vida de Mayra es la historia del racismo vivido por su madre. Una historia tan cercana que ha afectado también a Mayra:
Luego esta mujer malvada se fue a Estados Unidos, y mi mamá se conoce con mi papá y se casan, cuando llega esta mujer a Ecuador, casi enloquece de la ira, y le dice a mi mamá que si ella hubiera estado, ella nunca le hubiera dejado casarse, y peor aún de blanco si ella es solo una criada. (Cortez, 2012/2014: 2).

A partir de esta apertura hacia mi persona, Mayra y yo tuvimos varias reuniones y conversaciones en las que intercambiamos experiencias y puntos de vista. Posteriormente le compartí algunos textos de Aimé Césaire y de Frantz Fanon y Mayra me respondió a los pocos días de la siguiente manera:

[el texto de Fanon] lo leí; justo habla del complejo de inferioridad, que te contaba en el análisis que te envié, me parece interesante, lo que dice que perdemos nuestra esencia por vivir en un mundo de blancos, y hacerles frente a ellos, entonces la solución está en amarse a uno mismo tal y cómo es? amar nuestras raíces y luchar por tener una vida digna? no dejarse aplastar? no cruzarse de brazos? También me parece interesante el análisis sobre la sexualidad sobre los negros, desconocía todo eso, se puede decir que de cierta forma los blancos sienten complejo de inferioridad frente a la sexualidad de los negros? por eso son las bromas pesadas que hacen respecto a nuestra sexualidad? Aprendí algo nuevo. (Cortez, 2012/2014: 2).

Cada cierto tiempo Mayra retomaba este diálogo enviándome sus reflexiones:

Hago estas acotaciones, en referencia a lo que tú me contabas sobre romper las cadenas, a las que hemos estado esclavizados por generaciones, creo que en mi caso es el complejo de inferioridad, debido a que mi mamá fue tratada de esta forma, yo lucho constantemente contra eso, me sacudo, me revelo, y muchas veces trato de corregirle a mi mamá y explicarle ciertas cosas, poco a poco va entendiendo. Otra cosa contra la que me revelo y corto de raíz es el miedo al ¿Qué dirán? Muchas veces discuto por eso con mi mamá, pero igual poco a poco va entendiendo. (Cortez, 2012/2014: 2).

Invité a Mayra a pensar en formas de auto-representación que ella misma quisiera desarrollar. Así fue presentando semana tras semana sus apuntes al respecto:

Otra cosa con la que lucho es mi timidez, debido a que en la escuela tenía una maestra 
que me pegaba todos los días y me destrozó los nervios, pero estoy en un tratamiento con un homeópata y voy mejorando de poco a poco. Lo extraño es que cuando estoy actuando, no siento timidez, cuando actúo no soy tímida, pero cuando estoy fuera del escenario si lo soy..... ¿Qué cosa? (Cortez, 2012/2014: 2].

En un momento dado acordamos una sesión de retrato a ser desarrollada cuando ella lo sintiera oportuno; para ello le sugerí indagar en los modos de auto-percibirse, una ejercicio que Mayra abordó así:

Ya que estamos hablando sobre autoimagen, te cuento como me describo yo: aunque soy una persona tímida me considero una mujer encantadora, maravillosa, independiente, inteligente, demasiado sensible, alegre, emprendedora, optimista, soñadora, con mucha fuerza espiritual, divertida, bella, romántica, sensual, interesante, solidaria, prudente, silenciosa, una mujer que sabe lo que quiere y a donde va. (Cortez, 2012/2014: 2).

Mayra propuso entonces un proyecto de retrato en clave de foto-modelaje que, a partir de los referentes que reconoció en las cantantes afro-norteamericanas de 1930-50, definió así:

Voy a partir de la idea de que todas las mujeres llevamos una Diosa por dentro, por esta razón [...] esta sesión se podría llamar "El Esplendor de una Diosa" resaltando toda la feminidad, belleza, sensualidad, que puede tener una mujer, sin importar su raza, o clase social. Sobre todo me gustaría resaltar de manera especial la belleza de la mujer negra. Por esta razón se me ocurre hacer una foto en que la negrita, se mire al espejo, pero no se ve reflejada ella en ese instante, sino se ve ella a futuro convertida en una mujer hermosa "la cantante de Jazz o de boleros" (Cortez, 2012/2014: 2).

Así Mayra revisó fotografías de archivo de la famosa cantante de blues y jazz Della Reese:
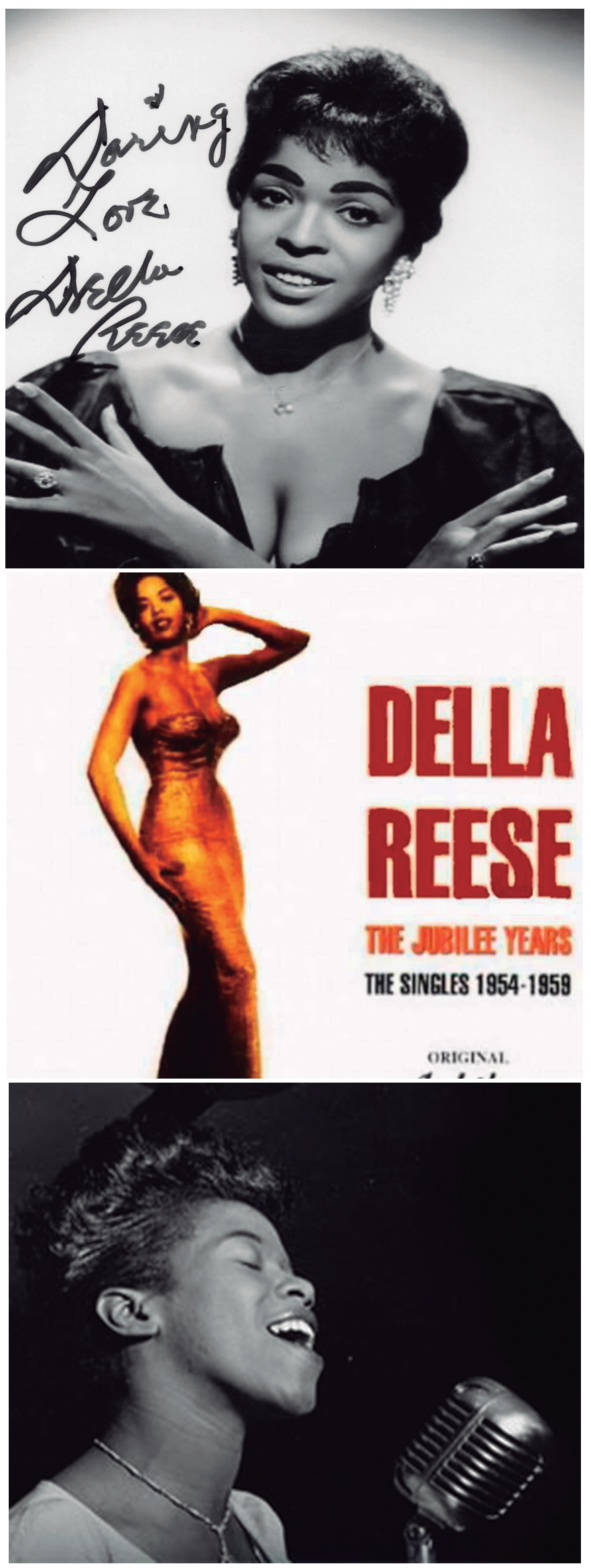

Imagen 3a-b: Retratos varios de Della Reese I-III; Fuente: Internet. 
Este diálogo con las imágenes de archivo nos llevó a cada uno a hablar sobre nosotros mismos. ¿Quiénes somos, cómo nos sentimos? Mayra respondió a la pregunta varios días más tardes con un correo electrónico con el que tomaba postura así:

en el mundo siempre ha habido racismo, y siempre lo habrá, pero lo que aprendí de todo esto es la manera como una reacciona a determinadas circunstancias, y por supuesto, antes de tener una actitud positiva, fui negativa, antes de ser valiente fui cobarde, y antes de amarme me odié, antes de creer en mí tuve dudas, pero solo equivocándome aprendí, y por eso elegí dejar de ser lastimosa y convertirme en poderosa (Cortez, 2012/2014: 2).

En las siguientes semanas Mayra trabajó con Daniela Sánchez4 con la que desarrolló esta estética referencial de la que Mayra se apropió para su reafirmación:

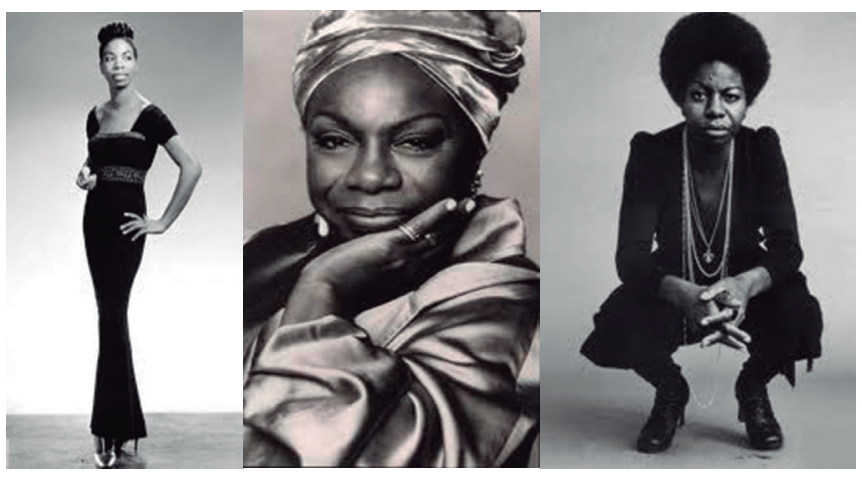

Imagen 4a-b: Referencias visuales de peinados 1-3, Fuente: Internet.

Finalmente realizamos una sesión de fotografías de retrato en la que Mayra desarrolló, en diálogo con el diseño de vestuario, peinado y maquillaje de Daniela, El esplendor de la diosa negra del jazz/blues de los años 1930-1950 en blanco y negro:

4. Una de las estrategias que he ido desarrollando en plataforma_SUR es la de "enganchar" determinados encuentros. Así, una vez que habíamos acordado producir la sesión de retrato fotográfico, presenté a Mayra con Daniela Sánchez, una joven directora de arte para cine y una profesional de gran personalidad; su presencia en cualquier proyecto se vuelve determinante ya que tiene un amplio conocimiento sobre el mundo escénico, especialmente en decorados, escenografía, vestuario, maquillaje y peinados. Daniela se interesó inmediatamente en el proyecto de Mayra y aceptó participar. Tras concertar una reunión las presenté brevemente y tras pocos minutos me retiré intencionalmente. De manera instantánea había surgido una relación de amistad y colaboración entre ambas.
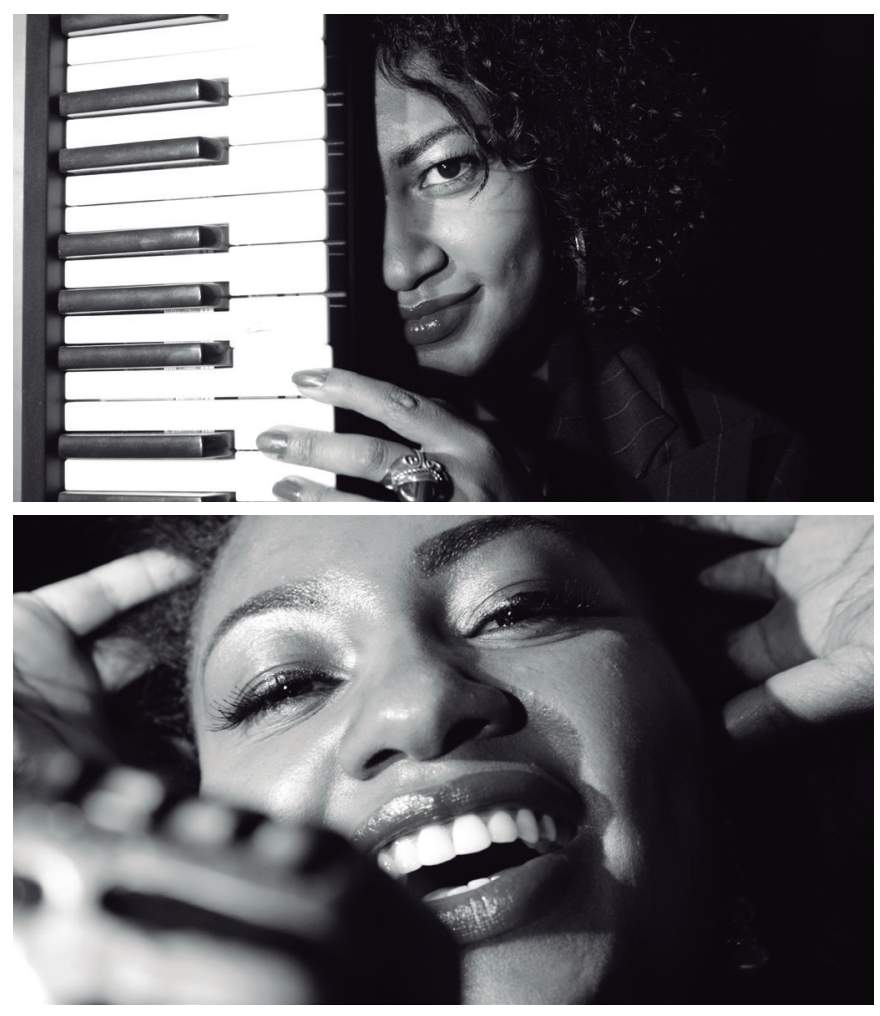

Imagen 5a-b: El esplendor de la diosa negra I-II, Fotografía: Alex Schlenker, Quito, 2012

A medida que fui tomando las fotos, le mostraba a Mayra aquellas que podían ser consideradas como "buenas". Cuando Mayra se vio retratada se motivó profundamente y se (re)conectó consigo misma:
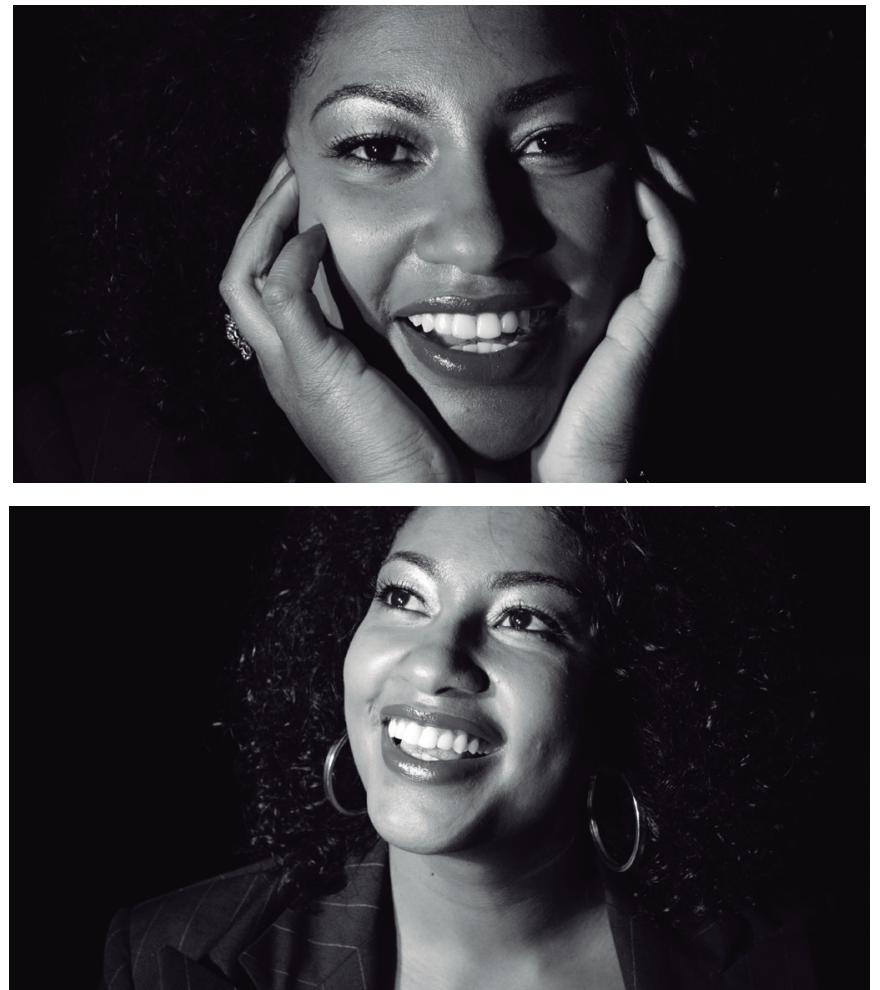

Imagen 6a-b: El esplendor de la diosa negra III-IV, Fotografía: Alex Schlenker, Quito, 2012 
En La opción decolonial Mignolo retoma las primeras ideas sobre colonialidad desarrolladas por Quijano, según las cuales el conocimiento es el campo de batalla desde donde se articula le retórica de la Modernidad y a partir del cual hay que pensar la liberación como un proceso de "descolonialización epistémica del ser y del saber" (Mignolo, 2008). "Lo fotográfico" opera en El esplendor de la diosa negra como la instancia que interpela y desmonta la asimetría según la cual el fotógrafo aparece como dueño de unos conocimientos que el retratado no tiene, estableciéndose así una posición de privilegio al momento de retratar al diferente, al otro, que es "fotografiado sin fotografiar"

Desarrollar retratos fotográficos como los que concibió Mayra Cortez en El esplendor de la diosa negra -ella dirigió con precisión toda la puesta en escena (posturas, objetos, gestos, etc.) con la que quería ser retratada- permite pensar en las posibilidades de re-existencia de quien le habla al mundo desde el rostro como lugar de reafirmación de la diferencia y de la identidad. Así, responder a la imagen archivo (atrapada en la fijeza inevitable de la fotografía-objeto) implica recordar la naturaleza ambivalente (positiva/ negativa) de la representación. Es necesaria tanto para la producción de significado, la formación de lenguaje y cultura, para identidades sociales y un sentido subjetivo del sí mismo como sujeto sexuado; y al mismo tiempo, es amenazante, un sitio de peligro, de sentimientos negativos, de hendidura, hostilidad y agresión hacia el «Otro». (Hall, 1997: 423). La respuesta que Cortez hace a los maltratos recibidos se vuelve el gesto de verse racializada, una acción violenta que configura la relación del uno sobre el otro; así Cortez apunta a trabajar en primera instancia en el uno, en la mismidad sobre la que se intentará fijar la mirada del colonizador. "Yo decido quién soy" responde la experimentadora, porque ella

sabe lo que es ser negr[a]...[cuando alguien dice: mira, una negra!] Fanon dice "fui fijado en esa mirada", que es la mirada fija de la Otredad. Y no hay identidad sin la relación dialógica con el Otro. El Otro no está afuera, sino también dentro del uno mismo, de la identidad. Así, la identidad es un proceso, la identidad se fisura. La identidad no es un punto fijo, sino ambivalente. La identidad es también la relación del Otro hacia el uno mismo. (Hall, 1997: 423).

5. El Subcomandante Marcos dirá que "no es lo mismo fusilar, que ser fusilado"; ver: Subcomandante Marcos, (1998), Carta de Marcos para 24 horas en el ciberespacio, de Internet, 8 de febrero de 1996, en EZLN, Documentos y comunicados 3, Ediciones Era, México DF.
Mayra Cortez responde a la representación que de ella han hecho (negrita, mamacita, negra rica, puta, etc.J con una contrarrepresentación (miren el esplendor de la diosa negra!J. En este proceso de hacerse respetar como humana la representación se vuelve central. Hall es firme en afirmar la importancia de la misma: "La noción de que la identidad está por fuera de la representación —que hay un sí mismo en cada uno de nosotros y que sólo luego se agrega el lenguaje en el cual nos describimos- es insostenible." (Hall, 1997: 423).

La estrategia central de Mayra pasa por el rostro. Es su rostro lo que le devuelve la dignidad al advertir un posible encuentro con otros rostros. Es en el entrecruzamiento de las miradas de los rostros que se descubre y construye el sentido por ella misma. Ello acontece en primera instancia a partir del contexto, de unos elementos del entorno a los que les adjudicamos la posibilidad de hablar por nosotros, aunque ello no haga falta:

El rostro es significación, y significación sin contexto. Quiero decir que el otro, en la rectitud de su rostro, no es un personaje en un contexto. Por lo general, somos un «personaje»: se es profesor en la Sorbona, vicepresidente del Consejo de Estado, hijo de Fulano de Tal, todo lo que está en el pasaporte, la manera de vestirse, de presentarse. Y toda significación, en el sentido habitual del término, es relativa a un contexto tal: el sentido de algo depende, en su relación, de otra cosa. Aquí, por el contrario, el rostro es, en él solo, sentido. Tú eres tú. (Levinas, s.f.)

Para Levinas "Rostro y discurso están ligados. El rostro habla. Habla en la medida en que es él el que hace posible y comienza todo discurso." Y ese posibilidad del rostro de hablar y decir conlleva una responsabilidad ontológica que en palabras de Levinas surge así:

desde el momento en que el otro me mira, yo soy responsable de él sin ni siquiera tener que tomar responsabilidades en relación con él; su responsabilidad me incumbe. [...] el otro no es próximo a mí simplemente en el espacio, o allegado como un pariente, sino que se aproxima esencialmente a mí en tanto yo me siento -en tanto yo soy- responsable de él [en una] relación intersubjetivas que es una relación asimétrica. (Levinas s.f.)

El fotógrafo puede disponer los elementos materiales de la puesta en escena, controlar la composición y otros elementos de la estética visual, incluso puede establecer una cierta postura (de pie, sentado, en el suelo, etc.); puede insinuar lo que el rostro de Mayra debería decir, pero no lo puede controlar. 


\section{Secuencia 2: "Fractales de familia" por Daniela Ortiz}

En Minga visual 11 la artista visual Daniela Ortiz desmembró a la representación de familia de la imagen Retrato de familia en una serie titulada fractales de familia. Ortiz es una artista visual que se desempeña como docente de arte a nivel primario y secundario; ha expuesto fotografía, instalación, objeto y grabado en importantes eventos en Ecuador y España. Su aproximación desde temas como la familia, los sentimientos y las ausencias la ha llevado a preguntarse por la importancia de lo afectivo en la relación de creación y lectura de la imagen. Su intervención en Minga visual partía de su auto-identificación como alguien que durante la época de colegio fue clasificada como "despistada...porque yo era muy soñadora y a veces me quedaba pensando en distintas cosas y me decían despistada y en algún momento por no estar atenta a lo que me decían mis profes, me empezaron a llamar 'la tonta' y me quedé con ese sobrenombre de tonta”. (Ortiz 2012/2014).

En el marco del laboratorio que desarrolló plataforma SUR Daniela se identificó con la imagen Retrato de familia, acerca de la cual dijo que: "la familia funciona como un concepto de unión visual, como la suma de papá...mamá...hijas...y aquí la joven negrita...; me interesa separar la familia en sus partes y ver qué pasa"; (Ortiz 2012/2014). Daniela escaneó de nuevo la imagen y la separó digitalmente obteniendo diversos "fractales ${ }^{6}$ de lo familiar" que sugieren nuevas combinaciones: él: padre; la madre, 5 hijas, un bebé y una joven afro; tres niñas; ella solita; él y ella. Los gestos de separación y reagrupación que propone Daniela se vuelven preguntas que sugieren una suerte de liminalidad -lo que al mismo tiempo es y no es-, aquello que Victor Turner (1988) llama el whatif, instancia de lo improbable, pero posible.

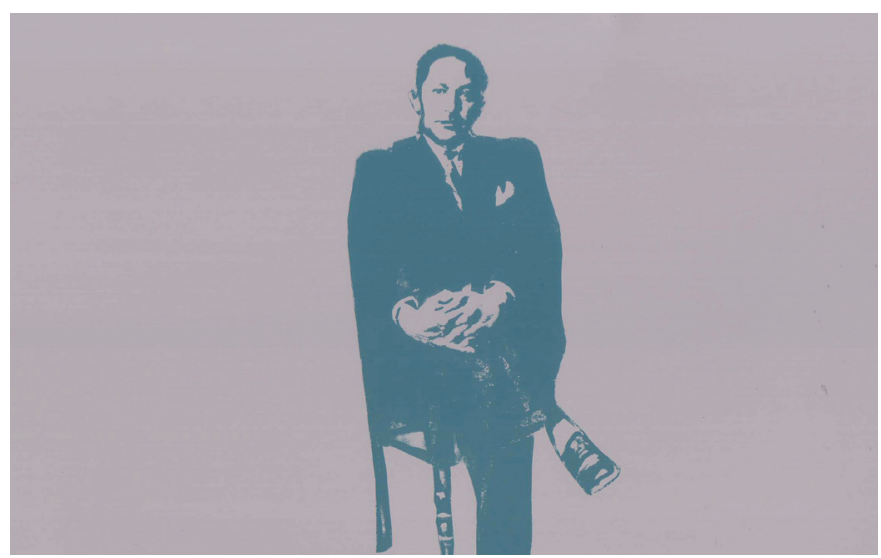

Imagen 7: Fractal I (detalle): él (padre); fotografía sobre metal. Fotografía: Daniela Ortiz, Quito, 2012.

6. Un fractal es una parte o fragmento de un todo cuya forma geométrica repite el mismo patrón del todo que la contiene. Ver: http://www.ub.edu/matefest_infofest2011/triptics/fractal.pdf
En la primera imagen (Fractal I) el efecto que logra Daniela Ortiz remite a una suerte de soledad del sujeto patriarcal, la cual se intensifica en el espacio vacío que Ortiz le asignó:

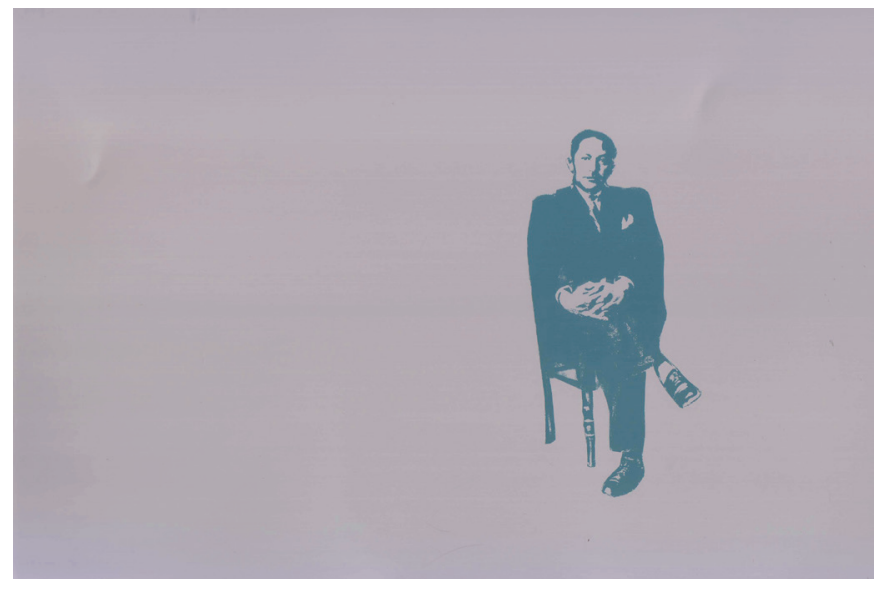

Imagen 8: Fractal I: el [padre]; fotografía sobre metal Fotografía: Daniela Ortiz, Quito, 2012.

Con el aislamiento del padre de familia, la figura del notable queda sin aquellas personas que deben reconocerlo como autoridad del hogar:

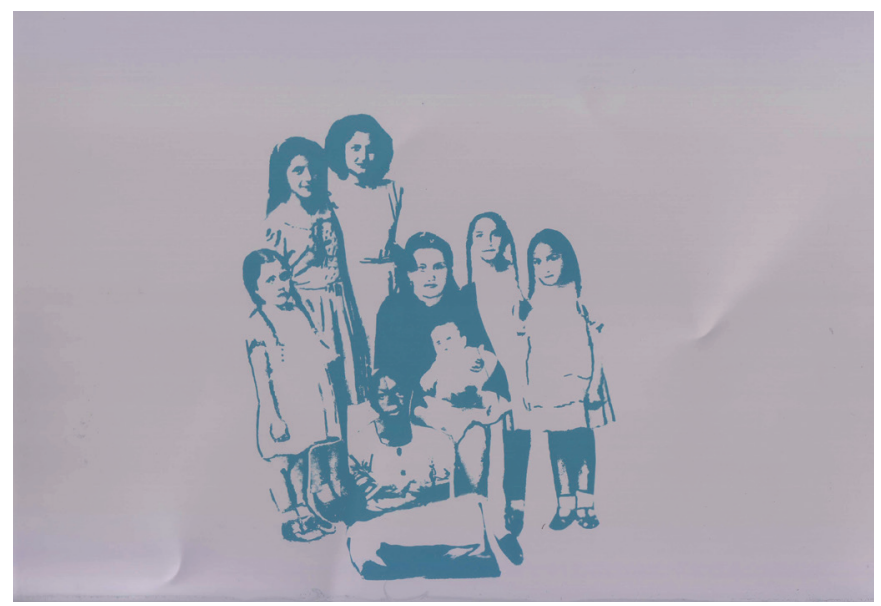

Imagen 9: Fractal II: madre, 5 hijas, un bebé y una joven afro; fotografía sobre metal Fotografía: D. Ortiz, Quito, 2012.

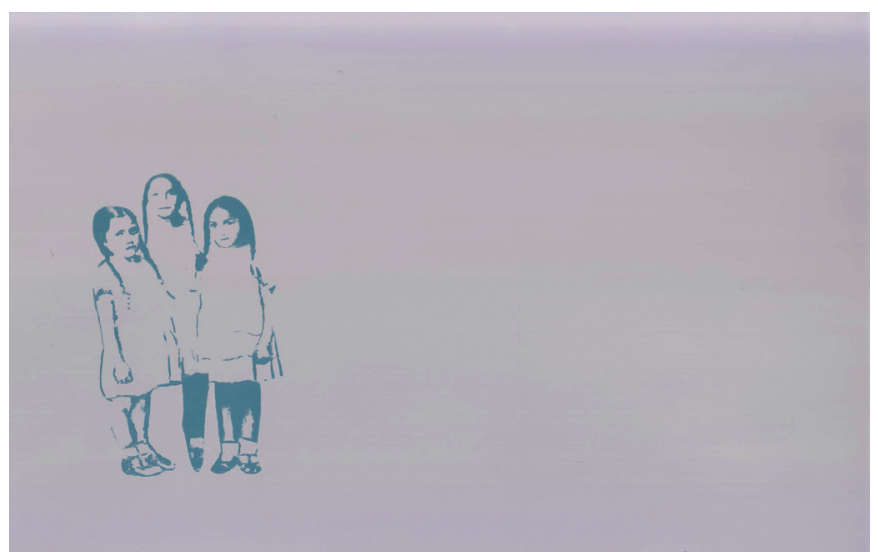

Imagen 10: Fractal III: tres niñas; fotografía sobre metal. Fotografía: Daniela Ortiz, Quito, 2012. 
Finalmente, como en un experimento de laboratorio, Daniela aisló a la joven afro y la reagrupó, primero frente a las siluetas de una cierta ausencia fantasmagórica que apunta a señalar la imposibilidad de la joven a ser por ella misma, sin la mediación de la instancia blanca-mestiza:

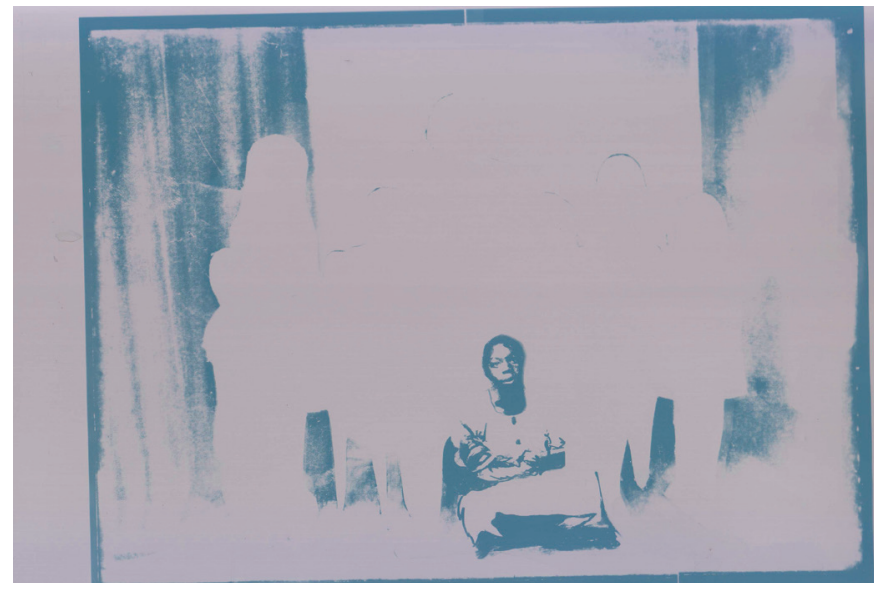

Imagen 11: Fractal IV: ella "solita"; fotografía sobre metal, Fotografía: Daniela Ortiz, Quito, 2012.

En un siguiente momento la artista se pregunta por la relación espacial y por ende social de dos polos marcados en la imagen: el hombre de traje y corbata en la silla y la joven afro, descalza y sentada en el suelo:

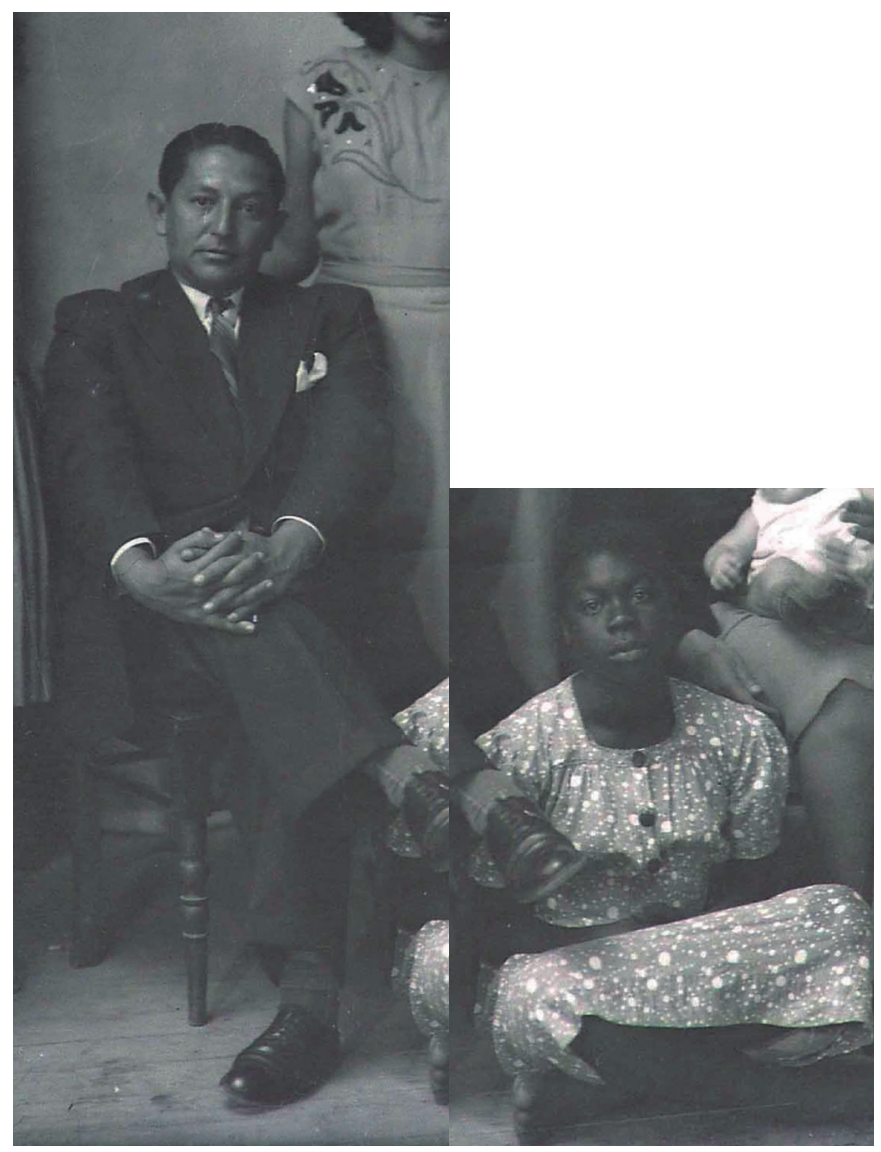

Imagen 12, 13: Retrato de familia (detalles b y c), Fotografía Estudio Rosales, 1930-40.
Esta disección resultó central para analizar las jerarquías de clase, étnicas, de género. Ortiz entonces reubicó a la joven de nuevo junto al patrón, al padre y jefe de la casa; un encuentro enmarcado por las siluetas de la madre y las hijas:

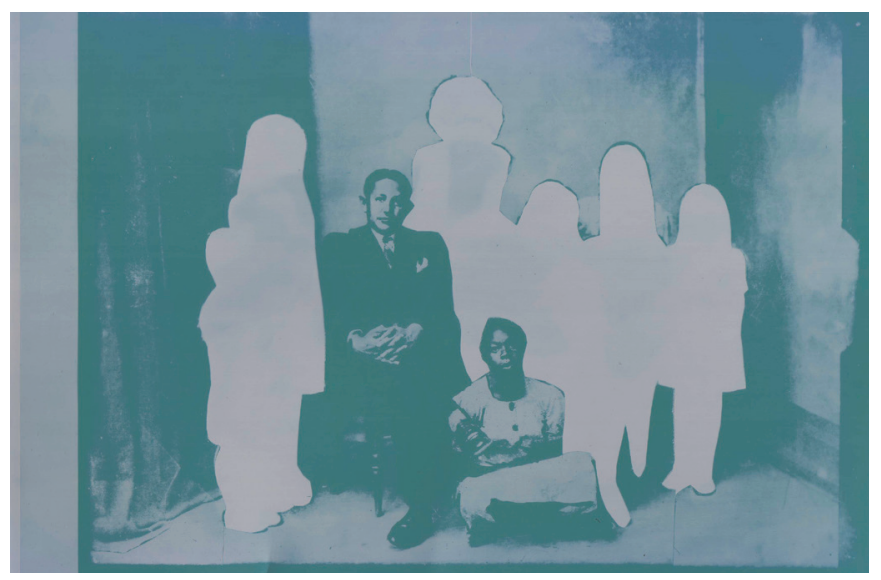

Imagen 14: Fractal V: él y ella; fotografía sobre metal Fotografía: Daniela Ortiz, Quito, 2012.

La intervención/apropiación que Ortiz hace de Retrato de familia apunta a desarticular las nociones de rol de género sobre las que se sostiene el imaginario de familia. Tal estrategia remarca la necesidad de pensar a la representación de género como la representación de un complejo entramado que además, para efectos de la presente serie, incluye la clase y la etnia. Tanto la joven afro como la esposa mestiza ocupan lugares subsumidos por el orden patriarcal. Tales formas de clasificación y control las acercan más de lo que ellas suponen, sin olvidar que tal exclusión tiene distintos niveles de intensidad y efectividad de acuerdo a la relación interseccional con otras jerarquías como por ejemplo en el nodo que he propuesto para la serie del presente capítulo: género-clase-etnia.

Intentar descolonizar una sola jerarquía y no las otras es restituir la colonialidad, especialmente si se pregunta desde el lugar del hombre blanco, ya que se estaría participando en la subsunción del conocimiento/pensamiento del otro. Tal paradoja, aquella que, al descolonizar un ámbito vuelve a colonizar otro, fue criticada por ejemplo por pensadoras del llamado feminismo chicano; Jo Carrillo dice en uno de sus textos:

A nuestras hermanas gringas / amigas radicales / les encanta tener retratos de nosotras / sentadas junto a la máquina de fábricas / manejando un machete / en pañuelos brillantes / cargando niños morenos amarillos negros rojos / leyendo libros de las / campañas contra el analfabetismo / cargando ametralladoras bayonetas bombas navajas / Nuestras hermanas blancas / 
amigas radicales deben pensarlo de nuevo [...] y cuando se vayan, llévense sus retratos [Carrillo, 1988: 79].

El desafío por anudar las diferencias de raza, clase, género implica pensar un modelo (temporal) que permita entender y desarrollar estos anudamientos como representaciones significativas - como preguntas de trabajo- para entrecruzar varias formas de clasificación/exclusión.

\section{Rasgar el archivo en minga [visual]: a modo de conclusión}

El acto fotográfico del retrato es un ritual en el que se encuentran fotógrafo y fotografiado. La imagen resultante es entendida comúnmente como un instante eterno o congelado. La fotografía de retrato es principalmente un ejercicio de encuadramiento del deseo de alguien de ser "eternizado" de cierto modo; la negociación tácita entre retratado y retratante enuncia y despliega, a través de una puesta en escena, una determinada diferencia que se vuelve fundamental para quien la enuncia. Esta diferencia se inscribe en las condiciones de dominación de determinados grupos blanco-mestizos sobre indios, negros, campesinos, clases populares, mujeres, etc.

Los legados fotográficos, como aquel del Foto Estudio Rosales, que a lo largo de América latina han sido rescatados para preservar el patrimonio visual de determinados grupos sociales no son tan solo un cúmulo de registros visuales del pasado. En muchos casos albergan una mirada histórica que representa a determinados grupos sociales como superiores frente a otros. Los imaginarios coloniales inscritos en estas formas de representación visual se han insertado en el inconsciente de buena parte de la sociedad y muchos siguen activos el día de hoy. Atacar tales formas de colonialidad implica (re)leer de manera crítica tales representaciones visuales en las cuales alguien sabía operar la cámara obteniendo así el control sobre la representación.

Las mingas visuales son una de tantas otras maneras para (re)leer tales representaciones. Su accionar se centra en generar una suerte de comunidad de observadores que despliega sobre imágenes como Retrato de familia una estrategia de mirar-con, como un acto de construcción de sentido de lo retratado. No se trata entonces de reconstruir determinados hechos históricos para definir si una determinada lectura es verdadera o falsa, sino en decidir qué hacer con tal interpretación. Para ello se articularon aproximaciones que, en una lectura casi forense de las narraciones visuales desplegadas al interior de la imagen de retrato, posibles (re)interpretaciones de lo retratado. La mirada recupera en esa especulación sobre lo representado solo fragmentos de lo que habría ocurrido aquel día y los conduce por otros rumbos. Los posibles sentidos que se desprenden de estos ejercicios amplían los sentidos originales de los distintos retratos. Los gestos escénicos/visuales que Cortez y Ortiz sugieren en ese sentido no son las últimas, ni la únicas interpretaciones, pero si unas formas posibles para interpelar la colonialidad al interior de ciertos retratos fotográficos.

Uno de los principios de la minga visual es el encuentro, la experiencia de compartir el lugar y el momento de manera significativa para un encuentro compartido de la vida. Ello implica disputarle tiempo al capitalismo vertiginoso. Es así como las mingas visuales se configuran como espacios de intercambio de reflexiones y laboratorio de proyectos que se proponen accionar desde su experiencia vital un desenganche frente a la colonialidad.

\section{Referencias}

Avanessian, Armen y Anke Hennig (s.f.). Präsens. Poetikeines Tempus, disponible en http://www.spekulative-poetik.de/ la traducción es mía.

Avanessian, Armen [s.f.), 'Die ästhetische Ordnung der Documenta 12', en www.sfb626.de/veroeffentlichungen/documenta_workshop/avanessian/ index.html

Carrillo, Jo (1988). Y cuando se vayan, llévense sus retratos, en Esta puente, mi espalda, Voces de mujeres tercermundistas en los Estados Unidos, editado por Cherrie Moraga y Ana Castillo y traducido por Ana Castillo y Norma Alarcón, IsmPress, San Francisco.

Cortez, Mayra (2012/2014). Conversaciones en torno a la Minga Visual (I y II), Documento digital, Quito, 2012.

Flusser, Vilem (2010). Hacia una Filosofía de la Fotografía, Sigma, México.

Hall, Stuart (1997). "El espectáculo del Otro" en: Representación: Representación Cultural y prácticas significantes, London: Sage/Open University Press.

Fontana, Juan Carlos y Jorge Lavelli (2004). EI teatro es un arte de sugestión, Revista Picadero Año 2, No. 11, Abril-julio 2004, Instituto Nacional de Teatro, Buenos Aires.

Levinas, Emmanuel (s.f.). El rostro o mi responsabilidad para con el otro, una conversación con Phillipe Nemo, Documento digital disponible en http://filosofaralos16. webnode.es/el-sentido-de-la-vida/levinas-el-rostro/ 
Mignolo, Walter (2008). La opción descolonial, Letral, Número 1, 2008, en http://www.proyectoletral.es

Sontag, Susan (2006). Sobre la Fotografía, Ediciones Alfaguara, Buenos Aires.

Subcomandante Marcos (1998). Carta de Marcos para 24 horas en el ciberespacio, de Internet, 8 de febrero de 1996, en EZLN, Documentos y comunicados 3, Ediciones Era, México DF.

Turner, Víctor (1988). The Anthropology of Performance, PAJ Publications, New York.

\section{Virtuales}

http://www.ub.edu/matefest_infofest2011/triptics $/$ fractal.pdf

http://filosofaralos16. webnode.es/el-sentido-de-lavida/levinas-el-rostro/

http://www.spekulative-poetik.de/

www.sfb626.de/veroeffentlichungen/documenta_workshop/avanessian/index.html

\section{Visuales}

Fondo Miguel Ángel Rosales, Universidad Andina Simón Bolívar-SE, Quito, Ecuador.

\section{Orales}

Ortiz, Daniela. Testimonio en el marco de Minga Visual 7/16, Quito, Octubre de 2012/septiembre 2014.

Potosí, María (53). entrevistada por plataformaSUR (a.schlenker; p.peralta; d.vasconez, 210), noviembre २3 de 2011. 


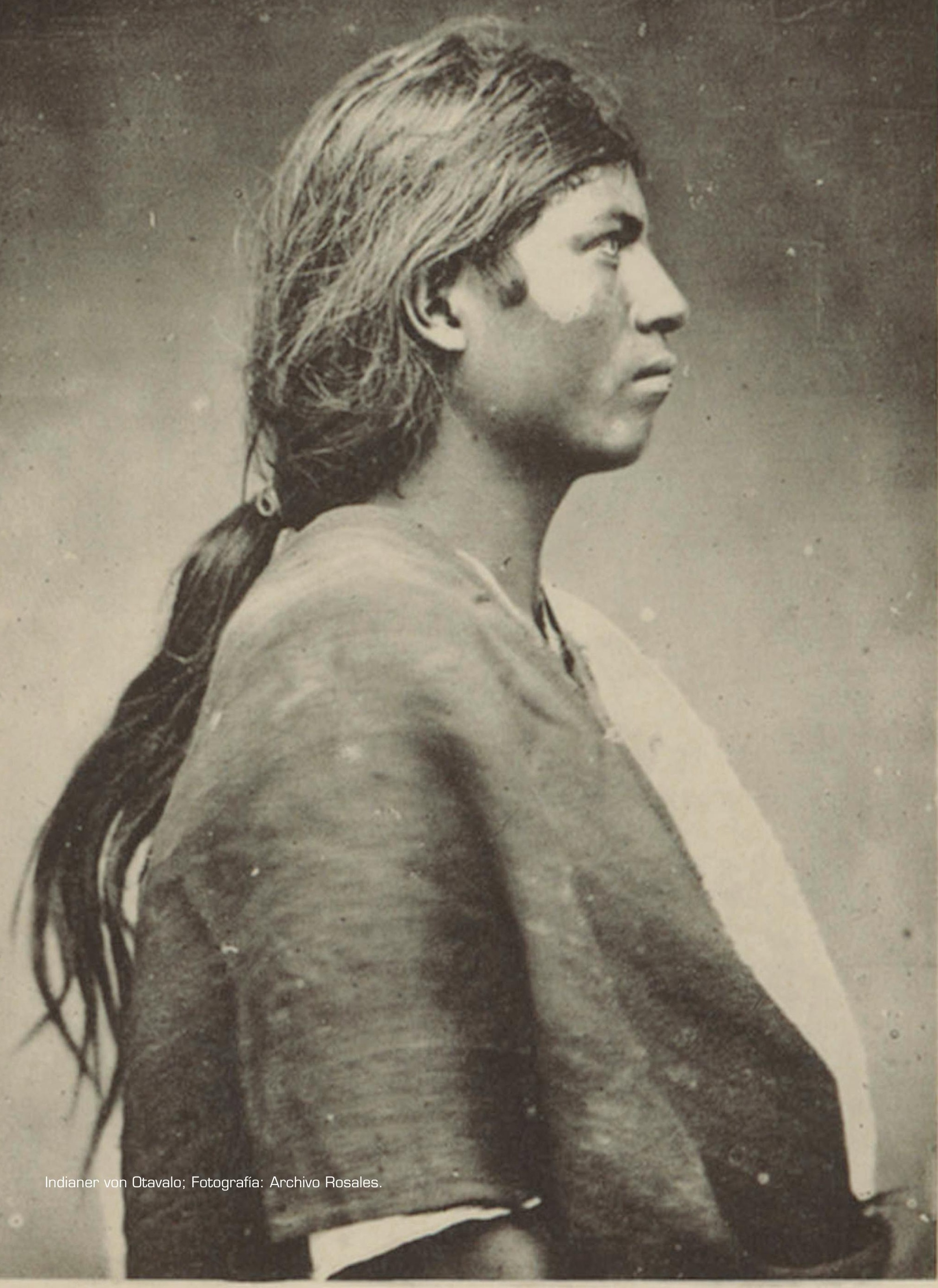

